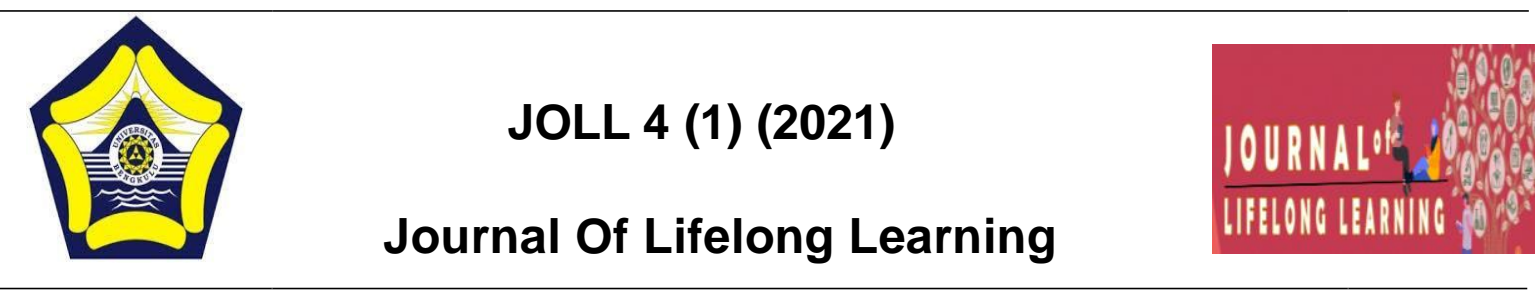

\title{
KEBERHASILAN YANG DICAPAI OLEH BAPAK YUKARI SEBAGAI PENGELOLA USAHA JUAL BELI KELAPA SAWI Erik Laorensyah ${ }^{1}$ Sofino $^{2}$
}

${ }^{1}$ Erik Laorensyah, Universitas Bengkulu eriklaorensyah19@gmail.com 3Sofino Universitas Bengkulu sofino@unib.ac.id

\begin{abstract}
The research objective was to describe the success of Mr. Yukari's palm oil trading business in Tanjung Tebat Village, Bunga Mas District, South Bengkulu Regency. There were three participants. This research is a qualitative research. Data collection techniques using interview techniques, observation and documentation. Data analysis techniques include data reduction, data presentation, and drawing conclusions. Checking the validity of the data used the triangulation technique. The results showed that the establishment of Mr. Yukari's business in 2014 with a capital of Rp. 150,000,000. The number of purchases of palm oil is currently 30 tonnes per day. Mr. Yukari's turnover is currently Rp. 6,00o,ooo per day. Mr. Yukari's current business profit is IDR 75,000,00o per month. Mr Yukari's assets are currently four transport cars, five trucks, and 13 hectares of oil palm land. The current number of employees is eleven employees. The external problem in Mr. Yukari's business is purchasing price competition. Mr. Yukari's solution is by considering price competition as a common thing and Mr. Yukari remains in his stance.
\end{abstract}

Keywords: Business Success, Buying and Selling, Palm Oil

\section{$\square$ Addresscorrespondence:}

Jl.W.R.Supratman,KandangLimun,MuaraBangkaHulu,

KotaBengkulu,Bengkulu3837 


\section{PENDAHULUAN}

Pendidikan merupakan salah satu faktor pendukung keberhasilan suatu bangsa, Indonesia sebagai negara berkembang harus mampu mengiringi kemajuan, perkembangan budaya untuk meningkatkan mutu pendidikan. Kebijakan pemerintah di bidang pendidikan dimaksudkan agar semua warga Indonesia memperoleh kesempatan yang sama untuk mengenyam dan mengikuti pendidikan yang berkualitas. Pemerintah telah mengupayakan kemudahan dalam memperoleh pendidikan dan harapan memiliki bangsa yang berpendidikan dan menghasilkan sumber daya manusia (SDM) Indonesia yang berkualitas.

Menurut Undang-undang No. 20 Tahun 2003 tentang jenis pendidikan (dalam Suprijanto 2012:6-8)“Jenis Pendidikan terbagi menjadi 3 (tiga) yaitu:1) Pendidikan Formal adalah jalur Pendidikan yang terstruktur dan berjenjang yang terdiri dari Pendidikan dasar, Pendidikan menengah, dan Pendidikan Tinggi2) Pendidikan Nonformal adalah jalur Pendidikan yang dilaksanakan di luar pendidikan Formal yang dilaksanakan secara terstruktur dan berjenjang, dan 3) Pendidikan Informal adalah jalur Pendidikan keluarga dan lingkungan yang berbentuk kegiatan belajar secara mandiri”.

Dalam Undang-Undang No 20 Tahun 2003 Pasal 26 Ayat 1 tentang Pendidikan Nonformal, berisi bahwa:"Pendidikan Nonformal diselenggarakan bagi warga masyarakat yang memerlukan layanan pendidikan yang berfungsi sebagai Pengganti, Penambah, dan/atau Pelengkap Pendidikan Formal dalam rangka mendukung Pendidikan Sepanjang Hayat"'

Dari pengertian diatas Pendidikan Nonformal berperan dalam memberikan pelayanan pendidikan kepada masyarakat yang menjadi pelengkap di bidang perekonomian yang dapat dikembangkan oleh sektor Pendidikan Nonformal adalah Kewirausahaan.

Kewirausahaan sebagai suatu proses penerapan kreativitas dan inovasi dalam memecahkan persoalan dan menemukan peluang untuk memperbaiki kehidupan (usaha). Artinya, untuk menciptakan sesuatu diperlukan suatu krativitas dan jiwa inovator yang tinggi, Zimmerer (dalam Kasmir 2019:20-21).

Kewirausahaan merupakan suatu kemampuan dalam hal menciptakan kegiatan usaha. Kemampuan menciptakan memerlukan adanya kreativitas dan inovasi yang terus menerus untuk menemukan sesuatu yang berbeda dari yang sudah ada sebelumnya. Kreativitas dan inovasi tersebut pada akhirnya mampu memberikan kontribusi bagi masyarakat banyak (Kasmir 2019:21).

Kewirausahaan dapat membantu proses pembangunan ekonomi suatu Negara. Hal ini dikarenakan dalam suatu kewirausahaan terdapat kreativitas, intuisi, dan mampu memanfaatkan peluang yang beroriantasi terhadap kebutuhan manusia dan sejalan dengan tren yang ada pada negara-negara maju dimana wirausaha sangat menonjol memainkan peranan penting dan bermutu dalam masyarakat.

Salah satu usaha yang berkembang pesat diKecamatan Bunga Mas Kabupaten Bengkulu Selatan adalah usaha jual beli kelapa sawit. Maka peneliti ingin melakukan penelitian yang berjudul "Keberhasilan Yang Dicapai Oleh Bapak Yukari Sebagai Pengelola Usaha Jual Beli Kelapa Sawit"

\section{METODE}

Pada penelitian ini peneliti menggunakan jenis penelitian yang bersifat deskriptif kualitatif. 
Metode penelitian kualitatif adalah metode penelitian yang digunakan untuk meneliti pada kondisi obyek yang alamiah, (sebagai lawannya adalah eksperimen) dimana peneliti adalah sebagai instrumen kunci, teknik pengumpulan dilakukan secara trianggulasi (gabungan), analisis data bersifat induktif, dan hasil penelitian kualitatif lebih menekankan makna daripada generalisasi (Sugiyono 2015:1)

Penelitian kualitatif adalah tradisi tertentu dalam ilmu pengetahuan social yang secara pundamental bergantung dari pengamatan pada manusia baik dalam kawasannya maupun dalam peristilahannya Kirk dan Miller 1986:9 (dalam Moleong 2017:4)

Tempat pelaksanaan penelitian ini yaitu Rumah kediaman Bapak Yukari beserta keluarganya di desa Tanjung Tebat kecamatan Bunga Mas Kabupaten Bengkulu Selatan, RAM Arirang (tempat jual beli kelapa sawit) di depan rumah bapak Yukari, dan tempat-tempat Bapak Yukari mengisi kegiatan lainnya. Waktu pelaksanaan penelitian dimulai pada tanggal 17 Februari - 07 Maret 2021. Adapun subjek penelitian ini yaitu Bapak Yukari selaku pemilik dan pengelolah usaha jual beli kelapa sawit, Ibu Wita Kosmirawati selaku istri dari Bapak Yukari, Bapak Egi Sutoyo selaku karyawan pada usaha jual beli kelapa sawit Bapak Yukari di Desa Tanjung Tebat Kec. Bunga Mas Kab. Bengkulu Selatan.

Teknik pengumpulan data dalam penelitian ini menggunakan Teknik wawancara, observasi dan dokumentasi.

Wawancara merupakan sebuah percakapan antara dua orang atau lebih, yang pertanyaanya diajukan oleh peneliti kepada subjek atau sekelompok subjek penelitian untuk dijawab (Susan Stainback dalam Sugiyono (2015:72)), Menurut Faisal (dalam Sugiyono,
2015:64) mengklasifikasikan observasi menjadi "observasi berpartisipasi, (participant observation), observasi yang secara terangterangan dan tersamar (covert observation dan covert observation), dan observasi tak berstruktur (unstructured observation) dan dokumentasi adalah catatan peristiwa yang sudah berlalu, dokumen bisa berbentuk tulisan, atau karya-karya monumental dari seseorang, dokumen yang berbentuk tulisan misalnya catatan harian, sejarah kehidupan, cerita, biografi, peraturan, kebjikan, sedangkan dokumen berbentuk gambar, misalnya foto, gambar hidup, sketsa dan lain-lain, kemudian dokumen yang berbentuk karya, misalnya karya seni, yang dapat berupa gambar, patung, film, dan lain-lain (Sugiyono 2015:82).

Sedangkan untuk teknik analisis data menggunakan tiga tahap yaitu, reduksi data, penyajian data dan menarik kesimpulan/verifikasi.

\section{HASIL DAN PEMBAHASAN}

A. Untuk mendeskrifsikan latar belakang berdirinya usaha jual beli kelapa sawit bapak Yukari

Berdasarkan Hasil Penelitian adalah Berdirinya usaha jual beli kelapa sawit bapak Yukari pada tahun 2014, adapun Alasan Bapak Yukari mendirikan usaha jual beli kelapa sawit karena, pada tahun 2014 bapak Yukari dan saudaranya sudah mempunyai kebun kelapa sawit berkisar 5000 pohon kelapa sawit dan sekali panen bisa sampai 2 truk daripada dijual pada orang lain lebih baik bapak Yukari sendiri yang menjualnya ke pabrik maka dari itu bapak Yukari berinisiatif mendirikan usaha jual beli kelapa sawit dan Modal awal 
usaha jual beli kelapa sawit bapak Yukari adalah 150.000.000 (seratus lima puluh juta rupiah).

Menurut Kasmir (2019:38) ada lima sebab atau cara seseorang untuk mulai merintis usaha, yaitu :

1. Factor keluarga pengusaha

Pengusaha yang memulai usaha karena factor keluarga cukup banyak ditemui. Artinya seseorang memulai usaha karena keluarga mereka sudah memilik usaha sebelumnya. Orang tua atau saudara pengusaha tersebut mengajari keluarga lainnya untuk membuka usaha sendiri.

2. Sengaja terjun menjadi pengusaha Sengaja terjun menjadi pengusaha, artinya seseorng dengan sengaja mendirikan usaha, biasanya mereka belajar dari kesuksesan orang lain.

3. Kerja sampingan Selanjutnya adalah melakukan usaha dengan tidak disengaja, biasanya dilakukan secara iseng.

4. Coba-coba

Memulai usaha dengan coba-coba cukup banyak dilakukan dan juga menuai kesuksesan.

5. Terpaksa

Factor usaha karena terpksa memang jarang terjadi, namun berdsasarkan hasil penelitian ternyata ada beberapa wirausahawan yang berhasil karena keterpaksaan.

Hasil sementara yaitu latar belakang Bapak Yukari mendirikan Usaha jual beli kelapa sawit yaitu karena bapak Yukari memiliki inisiatif dalam mendirikan usaha jual beli kelapa sawit serta adanya factor pendukug dari keluarga dan kesengajaan bapak Yukari yang ingin terjun menjadi pengusaha untuk memperoleh keuntungan.

B. Untuk mendeskripsikan wujud keberhasilan yang dicapai oleh Bapak Yukari sebagai pengelola usaha jual beli kelapa sawit

\section{Berdasarkan hasil penelitian adalah}

Bentuk keberhasilan bapak Yukari yang jelas kendaraan oprasional kerja bertambah seperti mobil pengangkut sawit dari lahan petani bertambah, mobil truk bertambah, adanya mobil pribadi,bertambahnya modal usaha dan bertambahnya lahan perkebunan kelapa sawit, Sumbangan dana social yang diberikan bapak Yukari, seperti sumbangan dana 17 agustus, sumbangan dana membangun masjid dan kegiatan di masjid dan Usaha lain yang dibangun bapak yukari pada saat ini adalah usaha jual beli pupuk nonsubsidi.

Menurut Kasmir (2019:30) menjelaskan tentang ciri wirausahawan yang dikatakan berhasil di antaranya:

1. Memilki visi dan tujuan yang jelas

Hal ini berfungsi untuk menebak ke mana langkah dan arah yang dituju, sihingga daoat diketahui apa yang akan dilakukan oleh pengusaha.

2. Insiatif dan selalu proaktif

Ini merupakan ciri mendasar di mana pengusaha tidak hanya mengunggu sesuatu yang terjadi, tetapi terlebih dahulu memulai mencari peluang.

3. Berorientasi pada prestasi

Pengusaha yang sukses selalu mengejar prestasi yang lebih baik daripada prestasi sebelumnya. Mutu produk, pelayanan yang diberikan, serta kepuasan pelanggan menjadi perhatian utama. 
4. Berani mengambil resiko

Hal ini merupakan sifat yang harus dimiliki seorang pengusaha kapan pun dan dimana pun, baik dalam bentuk uanh mapun waktu.

5. Kerja keras

Ide-ide baru selaulu mendorongnya untuk berkerja keras merealisasikannya. Tidak ada kata sulit dan tidak ada masalah yang tidak dapat diselesaikan.

6. Bertanggung jawab

Tanggung jawab seorang pengusaha tidak hanya pada material, tetapi juga moral kepda berbagai pihak.

7. Komitmen

Ciri yang harus dipegang teguh dan harus ditepati Komitmen untuk melakukan sesuatu memang merupakan kewajiban untuk segera ditepati dan direaliskan.

8. Mengembangkan dan memelihara hubungan baik dengan berbagai pihak. Baik yang berhubungan langsung dengan usaha yang dijalankan maupun tidak. Hubungan yang baik yang perlu dijalankan antara lain kepada para pelanggan, pemerintah,pemasok, serta masyarkat luas.

Hasil sementara bahwa keberhasilan usaha jual beli kelapa sawit Pak Yukari dan dapat dikatakan berhasil karena Bapak Yukari mempunyai ciri-ciri wirausahawan yang dikatakan berhasil di antaranya selalu inisiatif dan proaktif di lingkungan masyarakat, berani mengambil resiko, pekerja keras, bertanggung jawab pada semua pihak, komitmen dalam berusaha, dapat mengembangkan dan memelihara hubungan baik dengan semua pihak seperti pelanggan, karyawan, pemasok, pemerintah, dan masyarakat luas.

C. strategi yang dilakukan Bapak Yukari dalam mengembangkan usaha jual beli kelapa sawit

Berdasarkan hasil penelitian Cara bapak Yukari beintraksi dengan karyawan adalah dengan menganggap karyawan yang bekerja sebagai teman danadik-adiknya, namun tetap ada rasa segan karyawan terhadap bapak Yukari,dan cara Bapak Yukari berinteraksi dengan petani agar menjual hasil panen ke tempat usaha jual beli kelapa sawit miliknya adalah Dengan cara bapak Yukari dengan petani sawit sama-sama membutuhkan, apa saja keluhan petani itu didengar oleh bapak Yukari dan kalau dia bisa membantu pasti dibantu, misal petani membutuhkan pupuk di fasilitasi oleh bapak Yukari, petani membutuhkan pijaman uang di kasih oleh bapak Yukari tanpa adanya bunga.

Menurut Kasmir(2019:30) menjelaskan tentang ciri wirausahawan yang dikatakan berhasil di antaranya

1. Memilki visi dan tujuan yang jelas

2. Insiatif dan selalu proaktif

3. Berorientasi pada prestasi

4. Berani mengambil resiko

5. Kerja keras

6. Bertanggung jawab

7. Komitmen

8. Mengembangkan dan memelihara hubungan baik dengan berbagai pihak.

Hasil sementara yaitu bahwa strategi yang dilakukan Bapak Yukari dalam mengembangkan usaha jual beli kelapa sawitadalah dengan berani mengambil resiko, bertanggung jawab, mengembangkan dan memelihara hubungan yang baik dengan 
berbagai pihak baik yang berhubungan langsung dengan usaha yang dijalankan maupun tidak, seperti para pelanggan, karyawan, pemerintah setempat, dan masyarakat luas.

\section{Lokasi Bapak Yukari membeli kelapa sawit}

Berdasarkan hasil penelitian Lokasi bapak Yukari membeli kelapa sawit di tiga kecamatan yaitu kecamatan bunga mas, manna, dan kedurang. Lokasi paling sedikit bapak Yukari membeli kelapa sawit per hari adalah di kecamatan manna dan Lokasi paling banyak bapak Yukari membeli kelapa sawit adalah di kecamatan bunga mas. Lokasi bapak Yukari menjual kelapa sawit Di dua tempat yaitu PT CBS (citra bumi raflesia) di daerah kaur dan di PT APS di daerah padang guci.

Jual beli adalah persetujuan saling mengikat antara penjual, yakni pihak yang menyerahkan barang, dan pembeli sebagai pihak yang membayar harga barang yang dijual (KBBI 2002).

Jual beli diartikan sebagai menukar barang dengan barang atau barang dengan uang dengan jalan melepaskan hak milik dari yang satu kepada yang lain atas dasar saling merelakan Idris, 1986:5 (dalam Wati Susiawati 2017)

Hasil sementara pembelian dan penjualan kelapa sawit pada usaha jual beli bapak Yukari dilakukan dengan cara melepaskan hak milik dari petani kepada bapak Yukari dengan pertukaran uang dan kelapa sawit atas dasar saling merelakan.

\section{E. Jumlah pembelian kelapa sawit perhari pada awal berdirinya usaha}

Jumlah pembelian kelapa sawit per hari pada awal berdirinya usaha jual beli kelapa sawit bapak Yukari rata-rata 20 ton dan Jumlah pembelian kelapa sawit per minggu pada awal berdirinya usaha jual beli kelapa sawit bapak Yukari rata-rata 140 ton.

Menurut Kasmir(2019:30) menjelaskan tentang ciri wirausahawan yang dikatakan berhasil di antaranya

1. Memilki visi dan tujuan yang jelas

2. Insiatif dan selalu proaktif

3. Berorientasi pada prestasi

4. Berani mengambil resiko

5. Kerja keras

6. Bertanggung jawab

7. Komitmen

8. Mengembangkan dan memelihara hubungan baik dengan berbagai pihak

Hasil sementara adalah Bapak Yukari selalu melakukan pembelian kelapa sawit dari petani dengan berorientasi pada prestasi yang mana pelayanan kepada petani serta kepuasan petani menjadi perhatian utama dan Bapak Yukari selalu berkerja keras untuk kemajuan usahanya dan beranggapan tidak ada kata sulit dan tidak ada masalah yang tidak dapat diselesaikan.

\section{F. Jumlah pembelian kelapa sawit per hari pada saat ini}

Berdasarkan hasil penelitian Pembelian kelapa sawit pada usaha jual beli kelapa sawit bapak Yukari saat ini 30 ton per hari dan Pembelian kelapa sawit per minggu pada usaha jual beli kelapa sawit bapak Yukari saat ini berkisar 210 ton.

Menurut Kasmir(2019:30) menjelaskan tentang ciri wirausahawan yang dikatakan berhasil di antaranya

1. Memilki visi dan tujuan yang jelas

2. Insiatif dan selalu proaktif

3. Berorientasi pada prestasi 
4. Berani mengambil resiko

5. Kerja keras

6. Bertanggung jawab

7. Komitmen

8. Mengembangkan dan memelihara hubungan baik dengan berbagai pihak.

Hasil sementara adalah Bapak Yukari selalu melakukan pembelian kelapa sawit dari petani dengan berorientasi pada prestasi yang mana pelayanan kepada petani serta kepuasan petani menjadi perhatian utama dan Bapak Yukari selalu berkerja keras untuk kemajuan usahanya dan beranggapan tidak ada kata sulit dan tidak ada masalah yang tidak dapat diselesaikan

G. Omzet bapak Yukari per hari pada awal berdirinya usaha jual beli kelapa sawit

Berdasarkan hasil penelitian Omset bapak Yukari pada awal berdirinya usaha jual beli kelapa sawit sekitar 3 juta per hari dan Omset bapak Yukari pada awal berdirinya usaha jual beli kelapa sawit sekitar 21 juta per minggu

Omzet adalah jumlah uang hasil penjualan barang (dagangan) tertentu selama suatu masa jual (KBBI)

Pendapatan individu merupakan pendapatan yang diterima seluruh rumah tangga dalam perekonomian dari pembayaran atas penggunaan factor-faktor produksi yang dimilikinya dan dari sumber lain Sukirno 2002 (dalam Fatmawati M. Lumintang 2013)

Hasil penelitian sementara omset bapak Yukari adalah penghasilan kotor bapak Yukari dalam menjalankan usaha jual beli kelapa sawit baik per hari, per minggu ataupun per bulannya.

\section{H. Omset bapak Yukari per hari pada saat ini}

Berdasarkan hasil penelitian Omset usaha jual beli kelapa sawit bapak Yukari pada saat ini 6 juta per hari dan Omset usaha jual beli kelapa sawit bapak Yukari per minggu pada saat ini berkisar 42 juta.

Omzet adalah jumlah uang hasil penjualan barang (dagangan) tertentu selama suatu masa jual (KBBI)

Pendapatan individu merupakan pendapatan yang diterima seluruh rumah tangga dalam perekonomian dari pembayaran atas penggunaan factor-faktor produksi yang dimilikinya dan dari sumber lain Sukirno 2002 (dalam Fatmawati M. Lumintang 2013)

Hasil sementara Omset bapak Yukari adalah penghasilan kotor bapak Yukari dalam menjalankan usaha jual beli kelapa sawit baik per hari, per minggu ataupun per bulannya.

I. Keuntungan usaha jual beli kelapa sawit bapak Yukari per bulan pada awal berdirinya usaha

Berdasarkan hasil penelitian Keuntungan usaha jual beli kelapa sawit bapak Yukari per hari pada awal berdirinya usaha sebesar 1,5 juta, Keuntungan usaha jual beli kelapa sawit bapak Yukari per minggu pada awal berdirinya usaha sebesar 10,5 juta, dan Keuntungan usaha jual beli kelapa sawit bapak Yukari per bulan pada awal berdirinya usaha sebesar 45 juta.

Pendapatan merupakan penerimaan yang dikurangi biaya-biaya yang dikeluarkan. Pendapatan seseorang pada dasarnya tergantung dari pekerjaan dibidang jasa atau produksi, serta waktu jam kerja yang dicurahkan, tigkat pendapatan per jam yang 
diterima Pangandaheng 2012 (dalam jurnal Fatmawati M. Lumintang 2013).

Hasil sementara penghasilan bersih yang diterima bapak Yukari dalam menjalankan usaha jual beli kelapa sawit baik per hari, per minggu ataupun per bulannya.

\section{J. Keuntungan usaha jual beli kelapa} sawit bapak Yukari per bulan pada saat ini

Berdasarkan hasil penelitian

Keuntungan usaha jual beli kelapa sawit bapak Yukari pada saat ini berkisar 2,5 juta per hari, Keuntungan usaha jual beli kelapa sawit bapak Yukari pada saat ini sebesar 17,5 juta per minggu dan Keuntungan usaha jual beli kelapa sawit bapak Yukari pada saat ini sebesar 75 juta per bulannya.

Pendapatan individu merupakan pendapatan yang diterima seluruh rumah tangga dalam perekonomian dari pembayaran atas penggunaan factor-faktor produksi yang dimilikinya dan dari sumber lain Sukirno 2002 (dalam Fatmawati M. Lumintang 2013).

Hasil sementara penghasilan bersih yang diterima bapak Yukari dalam menjalankan usaha jual beli kelapa sawit baik per hari, per minggu ataupun per bulannya.

\section{K. Asset yang dimilik bapak Yukari pada awal} berdirinya usaha jual beli kelapa sawit

Berdasarkan hasil penelitian Jumlah mobil pengangkut kelapa sawit dari lahan petani pada awal berdirinya usaha jual beli kelapa sawit bapak Yukari berjumlah 2 buah mobil, Jumlah mobil truk pada awal berdirinya usaha jual beli kelapa sawit bapak Yukari sebanyak 1 buah dan Luas lahan kebun kelapa sawit bapak Yukari pada awal berdirinya usaha jual beli kelapa sawit seluas 1,5 hektar.
Keberhasilan usaha adalah keberhasilan dari bisnis dalam mencapai tujuannya suryana 2003:285 (dalam Lestari Fitria 2013)

Hasil sementara yaitu keberhasilan Bapak Yukari sebagai pengusaha jual beli kelapa sawit terlihat dari meningkatnya asset yang dimiliki bapak Yukari pada saat ini dari pada masa sebelumnya

\section{Asset yang dimiliki bapak Yukari sebagai pengusaha jual beli kelapa sawit pada saat ini}

Berdasarkan hasil penelitian Jumlah mobil pengangkut kelapa sawit dari lahan petani pada saat ini ada 4 buah mobil, Jumlah mobil truk pada usaha jual beli kelapa sawit bapak Yukari pada saat ini berjumlah 5 buah mobil dan Luas lahan kebun kelapa sawit bapak Yukari pada saat ini seluas 13 hektar.

Keberhasilan usaha adalah keberhasilan dari bisnis dalam mencapai tujuannya suryana 2003:285 (dalam Lestari Fitria 2013)

Menurut Kamus Besar Bahasa Indonesia (KBBI) Online, menyatakan bahwa "Keberhasilan adalah perihal (keadaan) berhasil

Hasil sementara yaitu keberhasilan Bapak Yukari sebagai pengusaha jual beli kelapa sawit terlihat dari meningkatnya asset yang dimiliki bapak Yukari pada saat ini dari pada masa sebelumnya

\section{Jumlah karyawan bapak Yukari pada awal berdirinya usaha jual beli kelapa sawit}

Berdasarkan hasi penelitian Jumlah karyawan pengangkut kelapa sawit dari lahan petani dan karyawan muat kelapa sawit pada awal berdirinya usaha jual beli kelapa sawit bapak Yukari berjumlah 4 orang karyawan dan 
Jumlah karyawan sopir truk pengangkut kelapa sawit ke pabrik pada awal berdirinya usaha jual beli kelapa sawit bapak Yukari berjumlah 1 orang karyawan.

Menurut Kasmir(2019:30) menjelaskan tentang ciri wirausahawan yang dikatakan berhasil di antaranya

1. Memilki visi dan tujuan yang jelas

2. Insiatif dan selalu proaktif

3. Berorientasi pada prestasi

4. Berani mengambil resiko

5. Kerja keras

6. Bertanggung jawab

7. Komitmen

8. Mengembangkan dan memelihara hubungan baik dengan berbagai pihak

Hasil sementara karyawan yang dimiliki bapak Yukari pada saat ini yang mana bapak Yukari selalu bertanggung jawab atas segala kinerja karyawannya baik itu hal baik maupun hal buruk dan bapak Yukari selalau mengembangkan dan memelihara hubungan yang baik dengan karyawannya

\section{N. Jumlah karyawan bapak Yukari pada saat ini}

Berdasarkan hasil penelitian Jumlah karyawan muat kelapa sawit ke dalam truk dan karyawan pengangkut kelapa sawit dari lahan petani pada saat ini ada 6 orang karyawan dan Jumlah karyawan sopir truk pengangkut kelapa sawit ke pabrik pada usaha jual beli kelapa sawit bapak Yukari saat ini ada 5 orang karyawan.

Menurut Kasmir(2019:30) menjelaskan tentang ciri wirausahawan yang dikatakan berhasil di antaranya

1. Memilki visi dan tujuan yang jelas

2. Insiatif dan selalu proaktif

3. Berorientasi pada prestasi

4. Berani mengambil resiko
5. Kerja keras

6. Bertanggung jawab

7. Komitmen

8. Mengembangkan dan memelihara hubungan baik dengan berbagai pihak Hasil sementara karyawan yang dimiliki bapak Yukari pada saat ini yang mana bapak Yukari selalu bertanggung jawab atas segala kinerja karyawannya baik itu hal baik maupun hal buruk dan bapak Yukari selalau mengembangkan dan memelihara hubungan yang baik dengan karyawannya

O. Kendala yang ditemukan bapak Yukari selama menjalankan usaha jual beli kelapa sawit

Berdasarkan hasil penelitian Kendala factor eksternal pada usaha jual beli kelapa sawit bapak Yukari adalah persaingan harga beli kelapa sawit dari petani antara bapak Yukari dan pengusaha jual beli kelapa sawit yang lainnya, Tidak ada kendala factor internal yang ditemukan oleh bapak Yukari dalam menjalankan usaha jual beli kelapa sawit miliknya dan Tidak ada kendala yang serius dan sulit untuk diatasi bapak Yukari dalam menjalankan usaha jual beli kelapa sawit.

Menurut Kasmir(2019:30) menjelaskan tentang ciri wirausahawan yang dikatakan berhasil di antaranya

1. Memilki visi dan tujuan yang jelas

2. Insiatif dan selalu proaktif

3. Berorientasi pada prestasi

4. Berani mengambil resiko

5. Kerja keras

6. Bertanggung jawab

7. Komitmen 
8. Mengembangkan dan memelihara hubungan baik dengan berbagai pihak.

Hasil sementara mengenai kendala usaha jual beli kelapa sawit bapak Yukari adalah masalah persaingan harga beli kelapa sawit antara bapak Yukari dengan pengusaha jual beli kelapa sawit yang lain, namun bapak Yukari berani mengambil resiko, dan komitmen terhadap apa yang telah menjadi keputusannnya

\section{P. Solusi yang dilakukan bapak Yukari dalam mengatasi kendala yang ditemukan}

Berdasarkan hasil penelitian Solusi yang dilakukan bapak Yukari dalam mengatasi kendala factor eksternal dengan cara menganggap persaingan harga itu hal yang biasa, bapak Yukaritetap pada pendiriannya walaupun harga beli bapak Yukari lebih murah dibandingkan harga beli pada usaha jual beli kelapa sawit yang lain, dan ada masyarakat yang membuat buruk namanya namunbapak Yukari menanggapinya tidak serius dan tetap pada pendirianya.

\section{SIMPULAN}

Usaha jual beli kelapa sawit bapak Yukari berdiri pada tahun 2014, Alasan Bapak Yukari mendirikan usaha jual beli kelapa sawit karena, Bapak Yukari dan saudaranya sudah mempunyai kebun kelapa sawit berkisar 5000 (lima ribu) pohon kelapa sawit dan sekali panen bisa sampai 2 (dua) truk, daripada dijual ke orang lain lebih baik Bapak Yukari sendiri yang menjualnya ke pabrik maka dari itu bapak Yukari berinisiatif mendirikan usaha jual beli kelapa sawit, Dengan modal awal usahasebesar Rp. 150.000.000 (seratus lima puluh juta rupiah).
Adapun wujud keberhasilan bapak Yukari sebagai pengelola usaha jual beli kelapa sawit yang jelas kendaraan oprasional kerja bertambah seperti mobil pengangkut sawit dari lahan petani bertambah, mobil truk bertambah, adanya mobil pribadi, bertambahnya modal usaha dan bertambahnya lahan perkebunan kelapa sawit, sumbangan dana sosial yang pernah diberikan bapak Yukari, seperti sumbangan dana 17 agustus, sumbangan dana membangun masjid dan kegiatan di masjid, selain ituada usaha lain yang dibangun bapak Yukari yaitu usaha jual beli pupuk nonsubsidi.

Cara bapak Yukari berinteraksi dengan petani agar menjual hasil panen ke tempat usaha jual beli kelapa sawit miliknya adalah Dengan cara bapak Yukari dengan petani sawit samasama membutuhkan, apa saja keluhan petani itu didengar oleh bapak Yukari dan kalau dia bisa membantu pasti dibantu, misal petani membutuhkan pupuk di fasilitasi oleh bapak Yukari, petani membutuhkan pijaman uang di kasih oleh bapak Yukari tanpa adanya bunga. lokasi bapak Yukari membeli kelapa sawit di tiga kecamatan yaitu kecamatan bunga mas, manna, dan kedurang. Lokasi bapak Yukari menjual kelapa sawit Di dua tempat yaitu PT CBS (citra bumi raflesia) di daerah kaur dan di PT APS di daerah padang guci.

Jumlah pembelian kelapa sawit per hari pada awal berdirinya usaha rata-rata 20 ton sedangkan jumlah per minggu pada awal berdirinya usaha berkisar 140 ton, Jumlah pembelian kelapa sawit pada usaha jual beli kelapa sawit bapak Yukari saat ini 30 ton per hari sedangkan per minggu pada saat ini berkisar 210 ton. Omset bapak Yukari pada awal berdirinyausaha jual beli kelapa sawit sekitar 3 juta per hari dan sekitar 21 juta per minggu, omset usaha jual beli kelapa sawit 
bapak Yukari pada saat ini 6 juta per hari dan per minggu berkisar 42 juta.

Keuntungan usaha jual beli kelapa sawit bapak Yukari per hari pada awal berdirinya usaha sebesar 1,5 juta, per minggu sebesar 10,5 juta, Dan per bulan sebesar 45 juta dan keuntungan usaha jual beli kelapa sawit bapak Yukari pada saat ini sebesar 2,5 juta per hari, 17,5 juta per minggu, Dan 75 juta per bulannya. Asset yang dimiliki bapak Yukari pada awal berdirinya usaha jual beli kelapa sawit yaitu mobil pengangkut kelapa sawit dari lahan petani pada awal berdirinya usaha berjumlah 2 buah mobil, jumlah mobil truksebanyak 1 buah, dan luas lahan kebun kelapa sawitseluas 1,5 hektar. Asset yang dimilik bapak Yukari pada saat ini ada 4 buah mobil pengangkut sawit dari lahan petani, 5 buah mobil truk, dan lahan kebun kelapa sawit seluas 13 hektar.

Jumlah karyawan pengangkut kelapa sawit dari lahan petani dan karyawan muat kelapa sawit pada awal berdirinya berjumlah 4 orang dan sopir truk pengangkut kelapa sawit ke pabrikberjumlah 1 orang karyawan. dan jumlah karyawan muat kelapa sawit ke dalam truk dan karyawan pengangkut kelapa sawit dari lahan petani pada saat ini ada 6 orang karyawan dan karyawan sopir sebanyak 5 orang karyawan. kendala factor eksternal pada usaha jual beli kelapa sawit bapak Yukari adalah persaingan harga beli kelapa sawit dari petani antara bapak Yukari dan pengusaha jual beli kelapa sawit yang lainnya, tidak ada kendala factor internal yang ditemukan oleh bapak Yukari dalam menjalankan usaha jual beli kelapa sawit miliknya, dan tidak ada kendala yang serius dan sulit untuk diatasi bapak Yukari dalam menjalankan usaha jual beli kelapa sawit. solusi yang dilakukan bapak Yukari dalam mengatasi kendala factor eksternal dengan cara menganggap persaingan harga itu hal yang biasa, bapak Yukari tetap pada pendiriannya.

\section{DAFTAR PUSTAKA}

Anwar, D. (2002). Kamus Lengkap Bahasa Indonesia. Surabaya: Amelia.

Kasmir. (2019). Kewirausahaan (edisi revisi). Depok: Rajawali Press.

Lestari, F. (2013). Pengaruh jiwa kewirausahaan dan kreativitas terhadap keberhasilan usaha pada sentra industri rajutan Binong Jati Bandung. Available at elib. unikom. ac.id, 8, 14-27.

Lumintang, F. M. (2013). Analisis Pendapatan Padi Didesa Teep Kecamatan Lawongan Timur. Jurnal EMBA

Moleong, L. J. (2017). Metodologi Penelitian Kualitatif. Bandung: PT Remaja Rosdakarya

Sugiyono. (2015). Memahami Penelitian Kualitatif. Bandung: Alfabeta.

Susiawati, W. (2017). Jual Beli dan Dalam Konteks Kekinian. Jurnal Ekonomi Islam, 172. 